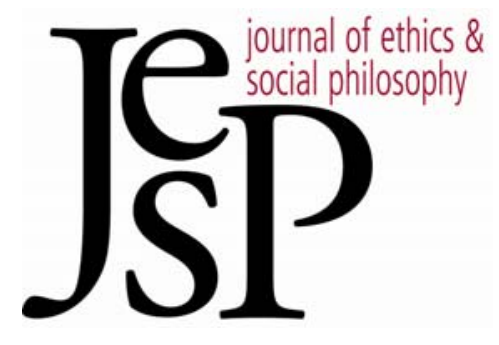

\title{
The Human Right to Political Participation
}

\author{
By Fabienne Peter
}

Journal OF ETHICs \& Social PHILOSOPHY

Vol. 7, NO. 2 | FEBRUARY 2013 URL: WWW.JESP.ORG COPYRIGHT @ FABIENNE PETER 2013 


\title{
The Human Right to Political Participation
}

\author{
Fabienne Peter
}

\section{CHE GROWING IMPORTANCE OF HUMAN RIGHTS after World War II set an end to the state-sovereignty doctrine as the main political norm in the global realm. Human rights became the} center of a distinctively political and legal agenda for the global order informed by egalitarian values. Human rights impose minimal binding standards both on domestic political institutions and the domestic legal order and on international relations and global institutions.

Insofar as human rights have, in this way, become part of the requirements of political legitimacy, the question arises as to how extensive the list of human rights should be. In the recent debate in philosophy, there has been a tendency to resist inflationary tendencies in the identification of what counts as a human right and to endorse minimalist lists of human rights. The right to political participation, in particular, although prominent in the original human rights treaties and in contemporary human rights practice, often fails to get support or is even explicitly excluded. Against these views, I want to defend the claim that a right to political participation should have a place even on minimalist lists of human rights.

My argument aims to show that human rights will fail to secure political legitimacy if the right to political participation is excluded from the set of basic rights. It hinges on a distinction between two problems of legitimacy that arise with human rights. The first, which we may call the problem of standards, relates to the requirement that political institutions and decisions - nationally, internationally and globally - apply and satisfy a human rights standard. Since a human rights standard is not the only requirement of legitimacy, the first problem concerns the relationship between a human rights standard and other sources of political legitimacy. In the context of a democratic state, for example, the problem of standards gives rise to the question of how a conception of democratic legitimacy can accommodate both a human rights standard and a principle of democratic self-determination. In the context of the international recognition of states, to give another example, the problem manifests itself in the question of how to weigh respect of human rights against restrictions on third-party interventions. This problem of standards is a reason for favoring minimalist lists of human rights.

The second problem of legitimacy, which is often obscured, concerns the justification of a human rights standard itself. I shall argue that because of this problem of justification, a human right to political participation is necessary - though not sufficient - for political legitimacy and should figure even on minimalist lists of human rights.

I shall end the paper with a discussion of what a right to political participation entails. The current debate focuses on whether or not there is a right to democracy (e.g., Christiano 2011a). I shall argue that the right to political participation need not be interpreted as a right to democracy, 
and I will defend a weaker requirement rather than the right to democracy. In another respect, however, my argument has a demanding implication. In contemporary human rights practice, the right to political participation is framed as a right to participate in national political affairs. My argument in support of the right to political participation implies that the right should be expanded to include participation in the global political debate as well, and I will briefly discuss this issue.

In sum, my paper defends the following main claims: (i) human rights are best understood in terms of their connection to political legitimacy; (ii) political legitimacy requires not merely that a human rights standard is applied and satisfied, but also that the standard itself is justified in the right way; and (iii) a right to political participation, suitably understood, is necessary, but not sufficient, for political legitimacy.

\section{Human Rights}

Before I can get to the main part of my argument, I need to say something about human rights in general. The idea of human rights has, of course, a long history in the natural rights tradition. But recent developments have inspired many to argue that the traditional conception of human rights - defined as rights people have "simply in virtue of their humanity" (Simmons 2001: 185) - ought to be replaced by a political conception. John Tasioulas (2009) helpfully identifies two main dimensions of disagreement in the current debate on conceptions of human rights. The first disagreement is about what human rights are and the second about how they are justified. According to the traditional conception, human rights are moral rights that people have qua salient features of their humanity. These features may relate to fundamental needs or interests (e.g., Miller 2012) or basic aspects of human agency (e.g., Griffin 2008). ${ }^{1}$ According to the political conception, by contrast, human rights are a set of special rights that have their origins in salient features of contemporary human rights practice (e.g., Rawls 1999; Beitz 2009). Just like traditional conceptions, political conceptions differ with regard to the relevant salient features. A prominent example is John Rawls' focus on third-party interventions (Rawls 1999).2 Other defenders of a political conception tend to give broader characterizations of contemporary human rights practice (e.g., Beitz 2009).

With regard to the question of what justifies human rights, defenders of the traditional conception typically maintain that ordinary moral reasoning is necessary and sufficient to establish what should count as a human right. Defenders of the political conception, by contrast, typically maintain that human rights are justified by some form of public reason or

\footnotetext{
1 According to Griffin (2008: 33), human rights are "protections of our human standing or ... our personhood," whereby our status as humans "centers on our being agents" (2008: 32).

2 According to Rawls (1999: 80), the fulfillment of human rights "is sufficient to exclude justified and forceful intervention by other peoples, for example, by diplomatic and economic sanctions, or in grave cases by military force."
} 
public reasoning. Human rights, on this view, are not discovered but constructed in an appropriately constrained process of practical deliberation. I shall discuss this dimension of the debate in greater detail a bit further down in this section.

Note that in addition to these pure forms of the traditional and the political conceptions of human rights, some writers have recently proposed mixed conceptions. Joseph Raz $(2007,2010)$ is, I think, best understood as defending a mixed conception. He accepts the political conception with regard to the first dimension - the question of what human rights are - but he combines this with the view that what justifies human rights is ordinary moral reasoning. Rainer Forst (2010) is drawn to the opposite move: He defines human rights on the basis of salient features of human agency, but answers the question of how they are justified by invoking an account of public reasoning. ${ }^{3}$

My sympathies are with the pure form of the political conception of human rights. I am unable to argue the case here, but I want to list a few considerations in favor of the political conception. ${ }^{4}$ First, one need not deny the historical thesis about human rights - that they emerged out of the natural rights tradition - in order to maintain that human rights were relaunched in 1948 as a specifically political-legal project. I follow Charles Beitz (2009) here, who argues that the historical thesis does not imply a philosophical thesis about what human rights are and about what explains the authority they have today. One can thus both accept the historical thesis and maintain that the best understanding of human rights today is one that breaks with the notion that human rights are moral rights that all individuals have in virtue of their humanity.

A second consideration is immediately related. Whatever the merits of interpreting human rights in light of the natural rights tradition, doing so is insufficient to capture the distinctive features of contemporary human rights practice. The contemporary practice identifies human rights with a set of explicitly political norms that only make sense in certain institutional contexts (Nickel 2007). Human rights get their distinctive content not from essential features of humanity as such, but from institutionalized relations between individuals and their governments and other political agents. The political conception of human rights is better equipped to capture this aspect of human rights practice than the traditional conception.

Third, it is not necessary to assume that human rights are essentially connected to some features of humanity to get a grip on the (important) idea that human rights are universal. Human rights are not timeless (e.g., Beitz 2009), but this does not mean that they are not universal. As Raz has convincingly argued, we can do justice to both the idea that what human rights are is rooted in contemporary practice and the idea that human rights are universal if human rights are understood as "synchronically universal," i.e., as rights that all people alive today have (Raz 2010:

\footnotetext{
3 See also Baynes (2009).

${ }_{4}^{4}$ See Beitz (2009) and Raz $(2007,2010)$ for forceful rejections of the pure traditional conception.
} 
41). This account of the universality of human rights is compatible with them changing over time.

Finally, and crucially for the argument I present in this paper, the relaunch of the human rights project in 1948 offers justificatory resources not available in the natural rights tradition. This gets me back to the question of what justifies human rights. What I have in mind is best explained through an analogy with Rawls' idea of a political conception of justice. As is well known, Rawls proposed to circumvent controversies about the morality of justice by developing a conception of justice based on fundamental political values embodied in democracy. The distinct - and very successful - political project that relaunched human rights, similarly, offers a way of circumventing the highly contested issue of the essential features that characterize human beings by instead offering an account based on more widely acknowledged features of contemporary human rights practice.

I am aware that this brief discussion only scratches the surface of the debate on conceptions of human rights. But even if the considerations I have listed do lend support to a political conception of human rights, there is still the question of what exactly it entails. I have already mentioned that Rawls took the main feature of contemporary human rights practice to be that international political agents are permitted to intervene and use coercion to enforce these rights (Rawls 1999). As James Nickel (2007: 98) has argued, however, Rawls' "ultraminimalist" interpretation of human rights neglects the multitude of roles that human rights serve. While it is true that some human rights serve as a basis for international intervention, this is by no means a central function of human rights. Other important functions are setting standards and aspirations for international political debate, for domestic politics, and for international treaties and international and global organizations. ${ }^{5}$

Nickel's thorough treatment identifies the following main features of contemporary human rights practice (2007: 9ff). Human rights are rights; they are associated with rightholders and addressees, and they require or forbid actions. They are universal, high-priority norms. Their scope is international. That is, they are "not dependent for their existence or recognition on enactment by particular governments" (2007: 10). In addition, they set "international standards for evaluation and criticism" (2007: $10)$, i.e., for global public reason. Finally, they apply primarily to political institutions and agents. While not specifying a blueprint for the global order, they define minimal standards for decent government conduct. ${ }^{6}$

Against this backdrop, it seems to me that the best way to interpret human rights is that they are individual rights associated with political legitimacy in a globalized world. On this conception, political legitimacy,

\footnotetext{
5 See Reidy (2006) for a defense of Rawls' interpretation.

${ }^{6}$ See also Beitz, who identifies three main elements in contemporary human rights practice (2009: 109): (i) human rights apply in the first instance to political institutions; (ii) they are "matters of international concern"; and (iii) they "protect urgent individual interests" against "standard threats" that arise from "life in a modern world order composed of states."
} 
not humanity, is the core concept that explains what human rights are.7 In what follows, I shall assume that human rights define a realm of equal standing in a globalized political world by setting limits on the decisionmaking procedures and actions of national governments and binding standards for international relations and global institutions.

\section{Human Rights and Cosmopolitan Legitimacy}

How exactly should the relation between human rights and political legitimacy be understood? To answer this question, I need to first say a bit more about political legitimacy.

Although this is currently changing, for a long time the default assumption has been that only the political institutions of nation states and decisions made within them give rise to a legitimacy problem. Political nationalism, as I want to call this view, is usually defended on the grounds that there is something unique about the coercion deployed by the nation state or about the political authority embodied in the nation state. This view clashes with the cosmopolitan understanding of legitimacy, according to which national communities are not the exclusive source of political legitimacy in the global realm. On a political cosmopolitan view, international or global standards are at least one source of national, international and, possibly, global legitimacy. This is a weak characterization. Political cosmopolitanism, thus defined, is compatible with a system in which nation states and their governments remain the main political agents, as long as there is some attribution of legitimate political authority to international conventions. But the definition does not rule out the much more demanding idea that nation states and national governments will be replaced - at least in certain policy areas - by global institutions. ${ }^{8}$

I believe that political nationalism is difficult to uphold today - for both empirical and normative reasons. The emergence of the contemporary human rights practice is one factor among others that challenges the political nationalist picture. Even though it is true that this practice owes its existence to conventions and treaties between individual states, human rights today, as mentioned above, are in effect independent of these states (as well as of states who were not initially involved). More generally, many have commented on how international and global institutions have started to take on roles traditionally limited to states and on the emergence of forms of governance in the global realm that are no longer reducible to state-led governance. Joshua Cohen and Charles Sabel, for example, argue that:

[t]o a substantial and growing extent ... rulemaking directly affecting the freedom of action of individuals, firms, and nation states (and the making of rules

\footnotetext{
${ }^{7}$ For an interpretation along these lines, see, among others, Joshua Cohen (2006), Jean Cohen (2008) and Gould (2008).

8 Cosmopolitan conceptions of legitimacy are discussed, for example, by Rawls (1999), Held (2002), Buchanan (2003 and 2008), Buchanan and Keohane (2006) and Besson (2010).
} 
to regulate this rulemaking) is taking place ... in global settings created by the world's nations but no longer under their effective control (2006: 765).

As Eric Cavallero (2010) argues with regard to the international property rights regime and Andreas Follesdal (2011) with regard to global institutions such as the World Trade Organization, the coercive power of these institutions relates to the fact that exit is not a viable option for individual states anymore, which implies that these institutions have a regulatory grip on people's lives beyond what can be controlled by their states. ${ }^{9}$

These developments have normative implications. If it is the case that international and global institutions issue rules that apply to individual, corporate and political agents, the question arises as to what distinguishes such rule-making from the mere exercise of power or from a de facto, but unjustified, claim to authority. If it is true, as I believe it is, that international and global rule-making is no longer fully in the control of nation states, then a political nationalist conception of legitimacy is incomplete and some form of political cosmopolitanism is required to address the normative challenges associated with international and global institutions.

How should we think about the legitimacy of such institutions? The answer depends on what conception of legitimacy is invoked. It will be helpful to distinguish between two broad approaches..$^{10}$ One influential view in the literature today can be traced back to John Locke (1980). What is distinctive about the Lockean view is that the normative source of legitimate authority is a substantive idea of social order that exists independently of the civil state. According to this view, whether an actual political regime - or any agent claiming de facto authority - is legitimate turns on whether it respects the relevant normative constraints. When a political authority oversteps these constraints, it ceases to be legitimate and, therefore, citizens are no longer obligated to obey its commands. As such, the Lockean conception of legitimacy is negative: It offers an account of when effective authority ceases to be legitimate. ${ }^{11}$ The contemporary literature has developed this Lockean approach in many ways, but its distinctive features are often seen: Legitimacy stands for what justifies political authority and the right to rule depends on respecting substantive normative criteria (e.g., Raz 1986).

\footnotetext{
9 In addition to Follesdal's article, see the other contributions to a special issue of Politics, Philosophy, and Economics on this topic, edited by Christiano (2011b).

${ }^{10}$ I shall focus on the concept of legitimate authority and simply bracket the question of whether legitimate authority entails political obligations; for an interesting recent answer to this question, see Applbaum (2010).

${ }^{11}$ It might be objected that this portrayal of the Lockean view neglects the role of consent. Consent plays a role in the account of how the transfer of authority ought to happen. But given Locke's wide interpretation of consent, its main function in his account is to capture the thought - contra Hobbes - that absolute authority is necessarily illegitimate because of its suspension of natural law. The source of legitimate authority is thus the natural law, not consent, but lack of consent is a marker of illegitimacy because it indicates the suspension of natural law. My reading of Locke follows that of Hannah Pitkin (1965: 991-99), among others. I thank David Miller for pressing me on this point.
} 
A consequence of this approach is that those who take the justification of authority to be the fundamental normative problem tend to downplay the problem of coercion. On this view, a political authority legitimately resorts to coercion to enforce the rights it is supposed to protect. ${ }^{12}$ On an alternative approach to political legitimacy, however, coercion is seen not just as a means to enforce a particular social order, but as constitutive of rights and hence of political authority. The implication of this alternative view is that rights are not unproblematic tools to secure an ideal social order, but are themselves coercive and in need of a particular justification.

In this alternative, Kantian, approach, political legitimacy is seen as related to the justification of coercion. ${ }^{13}$ The significance of coercion, in Kant's political philosophy, stems from his relational concept of rights. Rights, according to Kant, shape external relations between individuals, not the fulfillment of an isolated individual's interests. Kant, in the Metaphysics of Morals, motivates this way of thinking about rights in the following way. He recognizes freedom as the only natural ("innate") right, where freedom is defined as not being constrained in one's choices by the choices of others. For an individual in isolation, there is thus no threat to his or her freedom to choose. In a social context, however, the choices people want to make may clash with each other. The problem that arises in the social context in the state of nature is that each may want to put forward certain claims on others to respect their freedom, but there is no political authority that could adjudicate between conflicting claims. Rights are necessary to preserve the symmetry in individual freedom. But they are also constitutively coercive; they restrict the freedom to pursue one's own ends. Any right of a person - independently of whether it is respected or has been violated - implies a restriction for others (cf. Kant 6:231f; Ripstein 2004, 2009: 8; Flikschuh 2008: 389f). They key idea I want to use for my argument is that the creation of a system of rights and, with that, of political authority, is both necessary to secure freedom and constitutively coercive. This, in the Kantian approach, is the problem of legitimacy that a civil state faces.

Kant and Locke link the legitimacy of political authority to the social contract. But the two approaches obviously draw on different interpretations of the role of the social contract. The source of legitimate political authority for Locke lies in certain natural rights. Consequently, respect of an independent, substantive idea of how people should be ruled is what distinguishes legitimate from merely de facto political authority. The social contract is a vehicle to secure this idea in the civil state. For Kant, by contrast, the justification of a political order is not reducible to moral justification. On Kant's view, the social contract is a hypothetical thought experiment, meant to capture an idea of public reason, with the following

\footnotetext{
12 As Green puts the point, "[c]oercion threats provide secondary, reinforcing motivation when the political order fails in its primary normative technique of authoritative guidance" (1988: 75).

13 I have benefited greatly from Ripstein's (2004, 2009) and Flikschuh's (2008) recent discussions of Kant's political philosophy.
} 
criterion: Each law should be such that all individuals could have consented to it. (By public reason I mean the reason of all, rather than a substantive idea.) The focus is thus not on what can be justified, pace Locke, but on how justification ought to take place. As such, the social contract in Kant's political philosophy captures a procedural idea (Korsgaard 1997; Pallikkathayil 2010).

Returning to the main question of this paper, what follows from the two approaches for how to theorize the link between human rights and legitimacy? If we take the Lockean approach, human rights are instruments to secure a basic set of moral rights in the global political realm moral rights that limit the claims to authority that any political agent might make. Note that this approach is compatible with both a traditional and a Razian mixed conception of human rights. The Lockean approach suggests that human rights are minimal standards that define how people should be ruled.

This approach foregrounds what I have called the problem of standards: How might a human rights standard be weighed against other rights and other considerations that feature in conceptions of national and international or global legitimacy? In conceptions of domestic political legitimacy, the problem takes the form of how human rights might impose constraints on national governments. Consider the recent referendum proposal in Switzerland to ban the building of minarets as an example. An unusually high majority of the population approved of the ban. But the question remains as to whether this decision is illegitimate on grounds of violating human rights related to religious freedom. The first problem of legitimacy thus takes on the form of how to balance two sources of legitimacy: human rights and democratic decision-making. In the international and global context, this first problem of political legitimacy takes the form of spelling out the constraints that a human rights standard might impose on international relations and global institutions. An example for the global context is the legitimacy of humanitarian interventions, which concerns the question how the protection of human rights ought to be balanced with, say, state autonomy.

This first problem of legitimacy is important and much has been written about it. But there is a second problem of legitimacy that affects the relation between legitimacy and human rights, and this problem arises from the need to justify the human rights standard itself. Allen Buchanan describes this problem in the following way: "The more seriously the international legal system takes the protection of human rights and the more teeth this commitment has, the more problematic the lack of a credible public justification for human-rights norms becomes" (2008: 41). This second problem is in a sense more fundamental than the first, because if this problem is not solved, it is also not plausible to demand that national, international and global political institutions and agents ought to apply and satisfy a human rights standard as part of a requirement of legitimacy; illegitimacy might increase in the process.

Vasuki Nesiah (2009) has an excellent illustration of the significance of this second problem of legitimacy. Her analysis of recent human rights practice in relation to post-conflict situations reveals how the frame of 
war and mass violence has significantly shaped the content of human rights and the order of priority among human rights - in particular toward rights associated with humanitarian interventions such as food security. De-prioritized in this process were rights related to more long-term stability and security - political rights in particular - sometimes resulting in more violations even of the prioritized rights. Nesiah's conclusion is that the frame of war and mass violence has biased the justification of the human rights standard itself, with detrimental consequences. ${ }^{14}$

The problem with the Lockean approach to political legitimacy is that it tends to obscure this second problem. It suggests that human rights, as justified by ordinary moral reasoning, unproblematically provide protection from illegitimate interference from political institutions - national or otherwise. As we saw, the Kantian approach foregrounds the need to justify the coercion inherent in any system of rights. Human rights are no different. The Kantian approach as I have sketched it can recognize both problems of legitimacy: It can both explain why human rights form part of the constraints any political agent must respect and why there is a need to justify the human rights standard, as it is currently being created through human rights practice, on the basis of public reason.

The Kantian approach as I have sketched it supports a political conception of human rights. In the Metaphysics of Morals, Kant distinguishes between two types of rights: "strict rights" and "rights in the wider sense" (6:232ff). The latter allows for rights that express and aim to secure moral obligations. This interpretation of rights is compatible with the traditional conception of human rights as I have defined it in the previous section. I am interested here in the other type. A strict right, according to Kant, is "not mingled with anything ethical" (6:232). It does not express independently existing moral obligations, which would by themselves generate reasons for action and hence be internally binding, but mutually coercive external constraints. These rights are binding qua having been created as a right, not qua a moral obligation they might express. The focus on such rights is what distinguishes Kant's political philosophy from his moral philosophy.

Admittedly, as discussed above, Kant's political philosophy links the justification of strict rights to the protection of everyone's equal freedom, where freedom is conceived of as the only innate right (Kant 6:237). But this does not commit us to a moralized conception of human rights in the spirit of the traditional conception. Quite to the contrary. Kant is quite explicit that while some system of external constraints is required to protect freedom, there is no reason to expect that there is a unique system fit for the purpose.

If we follow the Kantian approach in this way, it helps to make sense of the political conception of human rights as I have characterized it in the previous section. The anchoring in freedom has to be loosened

14 "The specter of mass violence functions to legitimate and shape [an ethics and expertise-led human rights practice] at the expense of a closer interrogation of what is authorized in the name of rights in the shadow of war" (Nesiah 2009: 10). 
somewhat and replaced by the claim that human rights are rights that are created for the protection of equal standing in the globalized political world. ${ }^{15}$ More important for the purposes of this paper, it makes sense of the justificatory approach characteristic of the political conception of human rights. On the Kantian view as I have sketched it, justification depends not on moral rights people have qua their humanity, but on what the members of the global political community can justify to each other to count as minimal constraints for legitimate political authority in the global realm. ${ }^{16}$

A final point: The political conception of human rights that is compatible with the Kantian approach as I have sketched it is interestingly different from the interventionist version of the political conception. Even among those who in other contexts are considered Kantians there is a tendency to reduce human rights practice to something that functions as a global instrument to protect individual inalienable rights from state interference (e.g., Rawls 1999). We now have a better grasp of why this approach is too narrow: It not only offers an overly anemic interpretation of contemporary human rights practice, it is also based on an approach to the link between human rights and political legitimacy that obscures an important problem of legitimacy.

\section{Legitimacy and the Right to Political Participation}

I think it is the great advantage of the Kantian account that it can bring the second problem of legitimacy into focus. I now want to show how we can use this approach to support the claim that the right to political participation is a basic human right that cannot be excluded even from minimalist lists.

The Universal Declaration of Human Rights (1948) and the International Covenant on Civil and Political Rights (1966) both recognize a right to political participation.

Article 21 of the Universal Declaration of Human Rights states:

(1) Everyone has the right to take part in the government of his country, directly or through freely chosen representatives. (2) Everyone has the right of equal access to public service in his country. (3) The will of the people shall be the basis of the authority of government; this will shall be expressed in periodic and genuine elections which shall be by universal and equal suffrage and shall be held by secret vote or by equivalent free voting procedures.

The International Covenant on Civil and Political Rights has not only accepted this, but is more demanding. Its article 25 states that:

Every citizen shall have the right and the opportunity, without any of the distinctions mentioned in article 2 and without unreasonable restrictions: 1. To take part in the conduct of public affairs, directly or through freely chosen rep-

15 For a discussion of Kant's own proposal for the creation of legitimate authority in the global realm, as developed in the Doctrine of Right, and the difficulties that arise with that, see Byrd and Hruschka (2008) and Flikschuh (2010).

16 I am borrowing expressions from Joshua Cohen (2004) here. 
resentatives; 2. to vote and to be elected at genuine periodic elections which shall be by universal and equal suffrage and shall be held by secret ballot, guaranteeing the free expression of the will of the electors; 3 . To have access, on general terms of equality, to public service in his country.

While the right to political participation is thus part of these original agreements, its status as a human right has been the subject of many controversies, both in international law and in political philosophy. ${ }^{17}$

Many of these debates focus on the question of whether or not there should be a right to democracy. ${ }^{18}$ Before I can develop my argument in favor of the right to political participation, it is important to note that this right need not imply a right to democracy. I follow Henry Steiner (1988) here, who argues that full-fledged democratic participation is encouraged as a programmatic ideal but not required by human rights conventions. The reason is the following. The right to political participation has two parts: an "election clause" and a "take part" clause (Steiner 1988: 86). The take part clause is too vague to require any particular political system and would be satisfied by a right to participate in deliberative political processes. The elections clause is more specific, but it, too, can be satisfied by political systems other than democratic self-government as modeled, say, on modern Western democracies. Both clauses can thus be interpreted in ways that do not entail a democratic ideal of political equality. The right to political participation, understood in this way, neither presupposes democratic institutions nor does it demand that they be imposed where they are absent.

While more demanding interpretations of the right to political participation are not required, they are not excluded, of course. One indication of this is how both the Universal Declaration and the International Covenant allow for some leeway for democratically determined rights relative to the human rights included in the list. Many democratic societies have, of course, institutionalized extensive rights to political participation, with consequences for the relation between public reason and political participation. In such societies, an appropriately constrained democratic decision-making process is seen as necessary for political legitimacy. Some regional human rights conventions reflect this move toward democracy. The European Convention (1950), while not mentioning the right to participation, presupposes democracy (cf. article 11; Steiner 2008: 471). The American Convention (1969) includes both the right to political participation as characterized by the International Convention (article 23; Steiner 2008: 473) and a right to democracy (article 29; Steiner 2008: 473).

In many countries, political institutions that resemble those of a democracy are currently largely absent. In those countries, there is thus at

17 For discussions in international law, see Steiner (1988, 2008), Fox (1992), Franck (1992) and the recent debate in the European Journal of International Law with contributions by Marks (2011), d'Aspremont (2011) and Wheatley (2011).

18 Among philosophers, Joshua Cohen (2006), Griffin (2008: 243ff) and Beitz (2009) argue against the right to political participation interpreted as a right to democracy, while Christiano (2011a) argues in favor. See also Reidy (2012). 
the moment no institutional pull toward a right to democracy. ${ }^{19}$ One response to this situation is to treat democratic political participation as a programmatic ideal rather than a plausible characterization of what the right to political participation entails. If the relationship between the right to participation and democracy is understood in this way, the right to democracy is seen as an ideal that gives the legal right to political participation its specific content and aim, for example through a set of standards for the take part clause and the electoral clause. One implication of this view is that political participation that is not fully democratic is necessarily deficient in some ways. The recent literature on democratization (e.g., Carothers 2002) challenges the transitional paradigm, however, and an alternative view is taking shape. Based on research on new forms of political participation both in Western democracies and in countries with other political regimes, this alternative paradigm in democratization research focuses on the possibility of a stable coexistence of elements from different regime types - democratic and authoritarian - and examines the diversity of channels of political participation beyond traditional democratic electoral politics (e.g., Norris 2002).20 This view provides strong support for a more flexible characterization of the right to political participation that is not modeled on full-fledged democracy and that does not emphasize participation in elections at the expense of other forms of political participation.

Does the Kantian account support the right to political participation, understood in this weak sense? After all, as we saw above, the normative source of legitimacy, for Kant, is hypothetical consent. How does that idea support political participation? In reply, I want to argue that we can extract enough from Kant's treatment of legitimacy to support a human right to political participation. The argument builds on the relation between political legitimacy and public reason as I have developed it in the previous section. The role of public reason marks the key difference between the Kantian and the Lockean accounts of political legitimacy, primarily because of the procedural interpretation of the relationship between public reason and political legitimacy that we find in Kant. The Lockean account suggests that the human rights standard is justified independently of the political process and can be invoked to legitimize political authority. In the Kantian account, by contrast, the justification of a human rights standard is not independent of the political process. Kant's

19 This, I take, is also Charles Beitz' point (2009). Beitz, drawing on the large empirical literature on democracies and democratization, argues that the empirical circumstances do not support a right to democracy. But he supports democracy as an aspirational goal. In addition, James Nickel's proposal of interpreting human rights as "right-goal hybrids" is very promising here (Nickel 2010). The thought is that human rights have both a mandatory component and an aspirational component. Contemporary human rights practice encompasses both rights (the mandatory component) and goals (the aspirational component) where the two may set different standards. In relation to the right to political participation, democratic participation could be interpreted as part of the aspirational component, not the mandatory component.

20 This literature also takes a critical attitude toward the emphasis on elections that characterizes the transitional paradigm and the associated institution of election monitoring. See Kelley (2012) for a careful analysis of the pros and cons of election monitoring. 
emphasis on the authorization to make public use of one's reason to highlight legitimacy deficits (8:304) makes this clear. The thought is that without some right to participate in the deliberative process that constitutes public reason, there is no justification and hence no political legitimacy.

Understood in this way, the Kantian approach supports the right to political participation in the weak sense. True, public reason may be invoked to support a range of rights. But which other rights it can plausibly support is not important for my argument here. I am not trying to answer the general question of what human rights there are; I am only trying to argue that the right to political participation has its place even on minimalist lists, whatever else is on them. And what we can extract from the Kantian account is that the right to political participation in its weak interpretation, one that emphasizes taking part in deliberative processes but does not extend to a right to democracy, is prominent among them.

The final step of my argument concerns the scope of the public reason requirement. While the Kantian approach as I have sketched it is fairly undemanding with regard to the content of the right to political participation, it is potentially quite demanding with regard to its scope. The thought is best articulated in terms of the distinction I introduced earlier between political nationalism and political cosmopolitanism. If human rights are understood as a synchronically universal system of rights rights that, at any given moment in time, hold across political boundaries and, to some extent at least, independently of the attitudes of the governments of different states - then legitimacy requires that their justification, too, must transcend political boundaries. This implies that a political nationalist conception of political legitimacy is insufficient and that the public reason requirement must be understood in political cosmopolitan fashion.

The right to political participation, as it is currently interpreted, is limited to participation in matters of national governance. If my argument is correct, it demands that this right is extended to participation in global debates about rule-making through international and global institutions, including debates about the human rights standard itself. Political participation at the national level - whether in the form of participation in deliberative process, representation in what Rawls has called a consultation hierarchy (1999: 71ff), or democratic participation - will fail to establish legitimacy in a globalized world. To have legitimizing force in a context of globally binding constraints, public reason must similarly be global in reach.

But how should we make sense of global public reason? Luckily, the existing system allows for some participation in the global debate via participation in national or regional forums, and such participation may often suffice. For example, the optional protocol of the International Covenant on Civil and Political Rights, ratified by 113 out of the 165 countries that have ratified the main protocol, allows individuals to complain directly to the Human Rights Committee that one of the states has violated their human rights. The European Court of Human Rights also allows for direct complaints from individuals. It has generated a large body of 
jurisprudence on human rights and its cases often inspire public debate (Nickel 2007). Such channels can thus be used for contributions to the global political debate from within national or regional forums.

Nevertheless, a problem arises if these channels are insufficient for creating a global public reason. For example, issues of transnational regulation, such as those that arise with immigration, environmental protection or trade, especially if they involve forms of governance that are either not in the control of national bodies or biased toward the interest of some national states at the expense of others, may require a more immediately globalized debate. ${ }^{21}$ A right to take part in processes of public justification of political actions at the global level then becomes necessary to enable the kind of global public reason that political legitimacy requires. Vice versa, if political participation remains confined to participation in national debates, this will create a legitimacy deficit in cases where national public reason has insufficient reach. My argument thus implies that if present channels are insufficient, at least the take part clause of the right to political participation has to be extended to apply to deliberative processes beyond the national context. Additional channels - for example the creation of new courts that can address global issues - have to be created to facilitate participation in the global political debate, including debates about the justification of human rights standards. ${ }^{22}$

Fabienne Peter

University of Warwick

Department of Philosophy

f.peter@warwick.ac.uk

21 For discussion of this possibility and the response required, see especially Gould (2004, 2009).

22 I have greatly benefited from workshops organized by Rowan Cruft at the University of Stirling, as well as from seminars at Nuffield College Oxford, the London School of Economics, the University of Minho and the University of Warwick. I have received very valuable comments from, among many others, João Manuel Cardoso Rosas, Matthew Clayton, Rowan Cruft, Antony Duff, Katrin Flikschuh, Chandran Kukathas, Dean Machin, David Miller, Avia Pasternak, Massimo Renzo, Nicholas Southwood, Kai Spiekermann, Victor Tadros, Leif Wenar and Lea Ypi. Anonymous referees have also greatly helped me improve the paper. 


\section{References}

Applbaum, A. (2010) "Legitimacy Without the Duty to Obey," Philosopby and Public Affairs 38(3): 215-39.

Baynes, K. (2009) "Discourse Ethics and the Political Conception of Human Rights," Ethics and Global Politics 2(1).

Beitz, C. (2009) The Idea of Human Rights, Oxford: Oxford University Press.

Besson, S. (2010) "Theorizing the Sources of International Law," in S. Besson and J. Tasioulas, eds., The Philosophy of International Law, Oxford: Oxford University Press, pp. 163-85.

Buchanan, A. (2008) "Human Rights and the Legitimacy of the International Order," Legal Theory 14: 39-70. (2003) Justice, Legitimacy, and Self-Determination, Oxford: Oxford University Press. and Keohane, R. O. (2006) "The Legitimacy of Global Governance Institutions," Ethics and International Affairs 20(4): 405-37.

Byrd, B. S. and Hruschka, J. (2008) "From the State of Nature to the Juridical State of States," Law and Philosophy 27: 599-641.

Carothers, T. (2002) “The End of the Transition Paradigm," Journal of Democracy 13(1): 5 21.

Cavallero, E. (2010) “Coercion, Inequality and the International Property Regime," Journal of Political Philosophy 18(1): 16-31.

Christiano, T. (2011a) “An Instrumental Argument for a Human Right to Democracy," Philosophy and Public Affairs 39(2): 142-76. (2011b) "Introduction to Symposium on Ethical Dimensions of International Institutions," Politics, Philosophy \& Economics 10: 3-4.

Cohen, James and Sabel, C. (2006) "Global Democracy?” New York University Journal of International Law and Politics 37(4): 763-97.

Cohen, Jean (2008) "Rethinking Human Rights, Democracy, and Sovereignty in the Age of Globalization," Political Theory 36(4): 578-606.

Cohen, Joshua. (2006) "Is There a Right to Democracy?" in C. Sypnowich, ed., The Egalitarian Conscience, Oxford: Oxford University Press, 226-48.

(2004) "Minimalism About Human Rights: The Most We Can Hope For?" The Journal of Political Philosophy 12(2): 190-213.

Council of Europe (1950) European Convention for the Protection of Human Rights and Fundamental Freedoms, as amended by Protocols Nos. 11 and 14, ETS5, available at: www.unhcr.org/refworld/ docid/3ae6b3b04.html.

D'Apremont, J. (2011) "The Rise and Fall of Democracy Governance in International Law: A Reply to Susan Marks," European Journal of International Law 22(2): 549-70.

Flikschuh, K. (2010) "Kant's Sovereignty Dilemma: A Contemporary Analysis," Journal of Political Philosophy 18(4): 469-93. (2008) "Reason, Right, and Revolution: Kant and Locke," Philosophy and Public Affairs 36(4): 375-404.

Follesdal, A. (2011) “The Distributive Justice of a Global Basic Structure: A Category Mistake?" Politics, Philosophy \& Economics 10: 46-65.

Forst, R. (2010) "The Justification of Human Rights and the Basic Right to Justification: A Reflexive Approach," Ethics 120(4): 711-40.

Fox, G. (1992) “The Right to Political Participation in International Law," Yale Journal of International Law 17: 539-607.

Franck, T. (1992) “The Emerging Right to Democratic Governance," American Journal of International Law 86(1): 46-91.

Gould, C. C. (2009) "Structuring Global Democracy: Political Communities, Universal Human Rights, and Transnational Representation," Metaphilosophy 40(1): 24-41. (2004) Globaliqing Democracy and Human Rights, Cambridge: Cambridge University Press.

Griffin, J. (2008) On Human Rights, Oxford: Oxford University Press.

Held, D. (2002) "Law of States, Law of Peoples: Three Models of Sovereignty," Legal Theory 8(1): 1-44. 
Kant, I. (1996) Practical Philosophy, M. Gregor, ed. and trans., Cambridge: Cambridge University Press.

Kelley, J. (2012) Monitoring Democracy, Princeton: Princeton University Press.

Korsgaard, C. (1997) "Taking the Law into Our Own Hands," in A. Reath, B. Herman and C. Korsgaard, eds., Reclaiming the History of Ethics, Cambridge: Cambridge University Press, pp. 297-328.

Locke, J. (1980) Second Treatise of Government, C. B. Macpherson, ed., Indianapolis: Hackett.

Marks, S. (2011) "What Has Become of the Emerging Right to Democratic Governance?" European Journal of International Law 22(2): 507-24.

Miller, D. (2012) "Grounding Human Rights," Critical Review of International Social and Political Philosophy 15(4): 407-27.

Nagel, T. (2005) “The Problem of Global Justice,” Philosophy and Public Affairs 33(2): 113 47.

Nesiah, V. (2009) "The Specter of Violence that Haunts the UDHR: The Turn to Ethics and Expertise," in J. Mourin, ed., Human Rights Milestones: Challenges and Development in Asia, Bangkok: Asian Forum for Human Rights and Development, pp. 10-29.

Nickel, J. (2010) "Human Rights as Right-Goal Hybrids," unpublished manuscript. (2007) Making Sense of Human Rights, Oxford: Blackwell.

Norris, P. (2002) The Democratic Phoenix: Reinventing Political Activism, Cambridge: Cambridge University Press.

Organization of American States (1969) American Convention on Human Rights, "Pact of San Jose," Costa Rica, available at: www.unhcr.org/refworld/docid/3ae6b36510.html.

Pallikkathayil, J. (2010) "Deriving Morality from Politics: Rethinking the Formula of Humanity," Ethics 121(1): 116-47.

Pitkin, H. (1965) “Obligation and Consent I," American Political Science Review 59: 991-99.

Rawls, J. (1999) The Law of Peoples, Cambridge, MA: Harvard University Press.

Raz, J. (2010) "Human Rights in the Emerging World Order," Transnational Legal Theory $1(1): 31-47$.

(2007) "Human Rights Without Foundations," in S. Besson and J. Tasioulas, eds., The Philosophy of International Law, Oxford: Oxford University Press, pp. 321-37. (1986) The Morality of Freedom, Oxford: Oxford University Press.

Reidy, D. (2012) "On the Human Right to Democracy: Searching for Sense Without Stilts," Journal of Social Philosophy 43(2): 177-203.

(2006) "Political Authority and Human Rights," in R. Martin and D. Reidy, eds., Rawls's Law of Peoples: A Realistic Utopia? Oxford: Blackwell.

Ripstein, A. (2009) Force and Freedom, Cambridge, MA: Harvard University Press. (2004) "Authority and Coercion," Philosophy and Public Affairs 32(1): 2-35.

Simmons, A. J. (2001) Justification and Legitimacy, Cambridge: Cambridge University Press.

Steiner, H. (2008) "Two Sides of the Same Coin? Democracy and International Human Rights," Israel Law Review 41: 445-76.

(1988) "Political Participation as a Human Right," Harvard Human Rights Journal 1: 77-134.

Tasioulas, J. (2009) “Are Human Rights Essentially Triggers for Intervention?” Philosophy Compass 4(6): 938-50.

UN General Assembly (1966) International Covenant on Civil and Political Rights, United Nations, Treaty Series, vol. 999, p. 171, available at: www.unhcr.org/refworld/docid/3ae6b3aa0.html. (1948) Universal Declaration of Human Rights, 217A(III), available at: www.unhcr.org/refworld/docid/3ae6b3712c.html.

Wheatley, S. (2011) "A Democratic Rule of International Law," European Journal of International Law 22(2): 525-48. 